\title{
Can the legacy of industrial pollution influence antimicrobial resistance in estuarine sediments?
}

\author{
Kiri Rodgers ${ }^{1}$ - Iain McLellan ${ }^{1} \cdot$ Tatyana Peshkur $^{2} \cdot$ Roderick Williams $^{1} \cdot$ Rebecca Tonner $^{2} \cdot$ Andrew S. Hursthouse $^{1}$. \\ Charles W. Knapp ${ }^{2} \cdot$ Fiona L. Henriquez ${ }^{1}$
}

Received: 7 August 2018 / Accepted: 17 August 2018 / Published online: 13 October 2018

(c) The Author(s) 2018

\begin{abstract}
Antimicrobial resistance (AMR) represents a major global health threat, as well as a major hazard to sustainable economic development and national security. It remains, therefore, vital that current research aligns to policy development and implementation to alleviate a potential crisis. One must consider, for example, whether drivers of antibiotic resistance can be controlled in the future, or have they already accumulated in the past, whether from antibiotics and/or other pollutants? Unfortunately, industrial heritage and its pollution impact on the prevalence of environmental AMR have largely been ignored. Focussing on industrialised estuaries, we demonstrate that anthropogenic pollution inputs in addition to the natural diurnal environmental conditions can sufficiently create stressful conditions to the microbiome and thus promote selective pressures to shift the resistome (i.e., collection of resistance traits in the microbiological community). Unfortunately, the bacteria's survival mechanisms, via co-selective pressures, can affect their susceptibility to antibiotics. This review highlights the complexity of estuarine environments, using two key contaminant groups (metals/toxic elements and polyaromatic hydrocarbons), through which a variety of possible chemical and biological pollutant stressors can promote the emergence and dissemination of antimicrobial resistance. We find compelling divers to call on more focused research on historically disrupted ecosystems, in propagating AMR in the real world.
\end{abstract}

Keywords Antimicrobial resistance $\cdot$ Metals $\cdot$ Polyaromatic hydrocarbons $\cdot$ Environment $\cdot$ Microbiome $\cdot$ Pollution

\section{Introduction}

The development of bacterial antimicrobial resistance (AMR) represents a central contributor to ecosystem-mediate health impacts (Munita and Arias 2016). However, these "superbugs" not only develop from exposure to antibiotics, but also, among other factors, exposure to natural and anthropogenic conditions in their environment. As a survival strategy, some bacteria can acquire genes as an attempt to resist the stressors-e.g., SOS response (Beaber et al. 2004). Any acquired, or developed, resistance traits proven beneficially effective to their survival becomes retained in future

Kiri Rodgers

kiri.rodgers@uws.ac.uk

1 School of Science and Sport, University of the West of Scotland, Paisley, UK

2 Centre for Water, Environment, Sustainability \& Public Health, Department of Civil and Environmental Engineering, University of Strathclyde, Glasgow, UK generations and increases the prevalence of resistance genes within a single population. However, there are cases where resistance genes can become horizontally transferred on genetic elements to other bacteria; the unfortunate consequence is that recipient bacteria could be pathogenic. This, in summary, highlights the possibility that stressed bacteria could trigger genetic exchanges, which may ultimately lead to increased antibiotic resistance.

Antibiotics are pharmaceutical products used to fight bacterial infections and are considered a type of antimicrobial; sub-inhibitory exposures to antibiotics can result in bacteria developing a resistance as a natural adaptive reaction (European Centre for Disease Prevention and Control 2014; Lemire et al. 2013; Bernier and Surette 2013). Furthermore, this can be applicable to other micro-organisms such as fungi, viruses and some parasites, which collectively would be referred to as resistant organisms (World Health Organization 2018). These are known to be the cause of antimicrobial resistance. 
Furthermore, there has been an increase in pharmaceutical products within effluent introduced into water bodies (Larsson 2014); industrial effluent and pollution can be considered a major contributor to ARG presence which is discussed below.

Here, we focus on the conditions within estuaries and how they may stress the bacteria. The determination of AMR development (or retention) in estuarine systems is critical as they often represent highly impacted sensitive ecosystems: (1) they have historically been chosen for industrial and shipping activities; (2) they represent a major receptors and conveyors of pollutants that could, either currently or in future, threaten public or aqua-cultural health; (3) the confluence of marine and fresh waters continuously change in water properties, which can ecologically impact the microbiomes (communities of micro-organisms) with a range of sedimentary and geochemical conditions; and (4) the intertidal zones are globally the most densely populated regions (Martinez 2008).

In many developed nations, contemporary regulations help limit discharges into major estuaries, and many systems have (at least) begun the process towards ecological recovery. However, issues of legacy pollutants, which have been deposited and accumulated from past anthropogenic activities, often remain. People tend to investigate, remediate and minimise the risks associated with their chemical toxicity but often ignored (or not considered) are the biological risks that tend to be associated with past microbial depositions, but also their chronic exposure and adaptations to pollutants. Should we be concerned with increased bacterial risks due to legacy pollution - in particular, towards the development and dissemination of antimicrobial resistance?

It is no longer acceptable to state that AMR solely prevails from the selective pressures of antibiotics. Anthropogenic pollution "stress" and geochemical conditions promote genetic dissemination by cross and or co-resistance (Knapp et al. 2017; Ashbolt et al. 2013; Berg et al. 2010; Wright et al. 2006). As such, in this review, we examine the factors that contribute to antimicrobial resistance in environmental bacteria and whether pollution conditions in the estuarine environment could have an impact. We pay particular attention to the possible impact of legacy pollution, which may be: either ignored or unknown; assumed remediated or contained; or remain technologically or economically infeasible to treat.

\section{Industrial pollution in estuaries}

Industrial activity, whether contemporary or historical, has often occurred along major watercourses. However, adverse impacts include impaired water quality, habitat loss and diminished resources which results into poor water quality, deleterious changes in ecosystem structure and tropic dynamics, and risks to human and aquaculture health. Examples of investigations of historical environmental pollution events have included: The Clyde (Scotland), Nerbioi-Ibaizabal (Spain), Gironde (France) and Australian estuaries (Hursthouse et al. 1994; Birch et al. 2015; Rodriguez-Iruretagoiena et al. 2016; Larrose et al. 2010; Petit et al. 2015). On the Clyde and its tributaries, subsurface coal and ironstone mining, ship-building, textiles, chemical production and paper and engineering industries have all had a significant environmental impact on sediment quality during the conurbation of Glasgow in the nineteenth and twentieth centuries (Edgar et al. 1999, 2003). Consequently, the river Clyde has received pollution from the onset of the Industrial Revolution (AD 1770) up to the present day (Edgar et al. 2006; Vane et al. 2007, 2011), resulting in elevated PAH (polycyclic aromatic compounds) and PTE (potentially toxic elements, e.g., metal) concentrations.

Sediments are often considered "windows to the past". Deposition layers are created over time with distinct compositional changes and can highlight environmental conditions, e.g., the abundance and composition of siliceous diatom shells in sectioned sediments determine carbon dioxide trends (Friedlingstein et al. 2006). A relevant example is persistent toxic pollutants (e.g., metals) that can be linked to industrialisation as they do not degrade and are not easily mobilised in the sediment layers (Jordi 2016; Farmer 1991; Strzebońska et al. 2017). As such, legacy pollution involves layers of enhanced levels of contaminants from known human activities. They have been investigated to identify responsible parties for past discharges that have become a societal burden and require remediation-for example, $\mathrm{Cu}$ (copper), Mn (manganese) and As (arsenic) from abandoned brownfield sites (e.g., Castlebridge-colliery in Alloa, Scotland), and historical industries such as shipyards produce a variety of PTEs, oils, detergents and particulate matter (Papaioannou 2003; Oecd 2010). Additionally, legacy pollutants could include diffuse emissions representing a particular era of human activity, e.g., $\mathrm{Pb}$ (lead) from aerially deposited, widely dispersed combustion processes or mishandling of tetraethyl lead-amended petrol.

The existence of pollutants within wider environmental systems, in addition to increasing levels of discharge, is considered important contributing factors influencing antimicrobial resistance (Singer 2017). Their fate and bioavailability to the micro-organisms depend on environmental conditions, the chemical nature of the compound (e.g., sorption constant $K_{\mathrm{d}}$ ), affinities to minerals (e.g., Fe-Mn oxides and/or organic matter; (Peng et al. 2009; Konhausera et al. 2002; Akcil et al. 2015; Zaaboub et al. 2015), sediment properties (e.g., grain size, surface area to volume ratio, fine-grained sediments accumulate higher concentrations due to their greater surface area; (Eggleton and Thomas 2004), and additionally 
the composition and nature of the bacterial populations, and their innate abilities to resist and/or adapt to pollutant exposure.

\section{Dynamic nature of environmental conditions}

\section{Potentially toxic elements (PTEs)}

A number of PTEs [e.g., arsenic (As), cadmium (Cd), chromium $(\mathrm{Cr})$, copper $(\mathrm{Cu})$, mercury $(\mathrm{Hg})$, iron $(\mathrm{Fe})$, nickel $(\mathrm{Ni})$, lead $(\mathrm{Pb})$ and zinc (Zn)] (Besta et al. 2013) are included within the Water Framework Directive (2000/60/EC), and are classified as "priority substances" or "priority hazardous substances" in Annex II of Environmental Quality Standards Directive (2008/105/EC) (as amended by 2013/39/EU), and appear on the "key pollutant" list of the European Pollutant Release and Transfer Register (Cuculić et al. 2009; Khan et al. 2017; Larrose et al. 2010). Inputs of PTEs to an estuary depend on the (1) catchment area, (2) geological and soil erosion, (3) precipitation reactions, e.g., Fe/Mn oxides with organic matter, and (4) industry (Table 1). Although these elements are associated with anthropogenic stress on environmental systems, it has been reported that the major PTEs that affect estuarine health are $\mathrm{Pb}, \mathrm{Cu}$ and $\mathrm{Zn}$ (Birch et al. 2015); these have previously been found to be the triad of PTEs associated with anthropogenic influence in other ecosystems (Mclellan et al. 2013).

Using a "metal enrichment index" to determine the magnitude of anthropogenic induced change, Birch et al. (2015) found that human influence on estuarine health is more greatly impacted by high population density than high population; however, this is not always the case as industrial areas (i.e., intense, localised activity with low population density) will exhibit greater anthropogenic influence. Alongside the industrial emissions, infrastructure development affects the hydrodynamic and sedimentation patterns and conditions, therefore, will affect the sediment sorption and pollutant dispersal (Legorburu et al. 2013).

The highest concentrations of PTEs in sediments are found within the "convergence zone" between fresh water and marine water (i.e., within an estuary) due to the high turbidity (PTE sorption to suspended particulate matter) and $\mathrm{pH}$, which affects solubility, sorption and precipitation reactions (Caccia et al. 2003; Berner and Berner 2012; Petit et al. 2015). The association with the solid phase determines bioavailability and re-dissolution to the water column with mobility and bioavailability in the order of $\mathrm{Mn}>\mathrm{Cu}>\mathrm{Zn}>\mathrm{Fe}$ (Palleiro et al. 2016; Rodriguez-Iruretagoiena et al. 2016) suggesting that, based on natural versus human PTEs, anthropogenic inputs create greater environmental stress on sediment biota.

Determining the PTE source in estuarine sediments can be difficult due to (1) different sources for the same PTE, (2) bio-turbation between aerobic and anaerobic horizons, (3) continual mixing of top most sediment layer, (4) changing sediment inputs during seasonal changes and (5) dredging and bank restoration disrupting systems and bringing buried contamination to the surface and interfering with legacy tracking (Legorburu et al. 2013; Uncles et al. 2014). Often, multivariate approaches such as principal component analysis (PCA) are used, which allows us to correlate data according to cluster analysis, to elucidate inputs on a sitespecific basis.

\section{Polycyclic aromatic hydrocarbons (PAHs)}

PAHs are recalcitrant organic compounds that consist of conjoined aromatic rings; they are ubiquitous in the environment (Bosch et al. 2015; Choi et al. 2013) and have pyrogenic, petrogenic and biological sources. Pyrogenic PAHs are formed in high temperature $\left(>350^{\circ} \mathrm{C}\right)$, low oxygen conditions; biological PAHs are formed during degradation of vegetation material. Petrogenic PAHs are associated with oil maturation process, and major sources in the environment are from oil spills and releases of petroleum, oil and other transportation materials (Abdel-Shafy and Mansour 2016). There are hundreds of PAHs, although the "US EPA 16" is the most commonly studied in environmental systems: naphthalene, acenaphthylene, fluorine, phenanthrene, anthracene, fluoranthene, pyrene, benz[a]anthracene, chrysene, benzo[b]fluoranthene, benzo[k]fluoranthene, benzo[a]pyrene, benzo[g,h,i]perylene, dibenz[a,h]anthracene and indeno[1,2,3-c,d]pyrene; a number of these are listed as "priority hazardous substance" list (2008/105/EC as amended), including anthracene, benzo[a]pyrene, benzo[b]
Table 1 Sources of PTEs within sediments

\begin{tabular}{lll}
\hline $\mathrm{PTE}$ & Source & Citation \\
\hline $\mathrm{Cr}, \mathrm{Cu}, \mathrm{Mn}, \mathrm{Ni}, \mathrm{Pb}, \mathrm{Zn}$ & Agriculture: fertiliser application & Caccia et al. (2003) \\
$\mathrm{Cd}, \mathrm{Co}, \mathrm{Cr}, \mathrm{Cu}, \mathrm{Sn}, \mathrm{Zn}$ & Boat traffic & Caccia et al. (2003) \\
$\mathrm{Mn}$ & Wastewater treatment works & Rodriguez-Iruretagoiena et al. (2016) \\
$\mathrm{Al}, \mathrm{Co}, \mathrm{Fe}, \mathrm{Mg}, \mathrm{Mn}, \mathrm{Ni}$ & Geology & Birch et al. (2015) \\
$\mathrm{Pb}$ & Leaded petrol & Lenart-Boroń and Boroń (2014) \\
\hline
\end{tabular}


flouranthene, benzo[g,h,i]perylene, benzo[k]flouranthene, indeno[1,2,3-c,d]pyrene and naphthalene.

The number of rings reflects the origin from which they were derived; i.e., lower molecular weight compounds are typically natural in origin, whilst higher weights tend to be anthropogenic (Yan et al. 2009). Studies have shown that "total PAH" concentrations (i.e., summation of US EPA 16) often increase with sediment depth (Curtosi et al. 2007; Ke et al. 2005) and that up to $89 \%$ of these PAHs consisted of four-six rings at all depths (Li et al. 2009)i.e., anthropogenic sources. Furthermore, PAHs have been proven to increase in industrial areas (Huston et al. 2009). "Total PAH" abundances have been quoted to vary greatly across the world with Scottish sediment studies ranging $150->750 \mu \mathrm{g} \mathrm{kg}^{-1}$ (Webster et al. 2001), estuary sediments

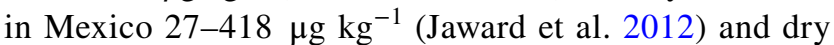
sediments in Japan 21-1447 $\mu \mathrm{g} \mathrm{kg}^{-1}$ (Onozato et al. 2016).

PAHs have a high tendency to bio-accumulate and cause eco-toxicological concerns (Schwarzenbach et al. 2003; Sawulski et al. 2014; Atsdr, 2005). As a consequence, they have been extensively studied to better understand their environmental fate, distribution and effects (Haftka 2009; Pavlova and Ivanova 2003). The environmental origin of PAHs in sediments typically comes from atmospheric mixtures (and particulate matter-soot), consisting of four rings or more that readily adsorb onto particulate matter and subsequently become deposited into sediment due to weak water solubility (Skupinska et al. 2004).

As a consequence of their non-polar structures, they are unlikely to dissolve in waters. Hydrophobicity increases with the number of aromatic rings, and larger PAHs which have a potential anthropogenic source are less environmentally mobile and bio-available or subject to microbial degradation (Sawulski et al. 2014). Further, in estuarine (and other) systems, the dissolved organic matter (DOM) is the driving force for the absorption of hydrophobic pollutants, and changes in salinity affect the movement of DOM. Increasing salinity causes DOM to partition from water to sediments, and vice versa (Kafilzadeh 2015; Li et al. 2009; Chapman and Wang 2001).

Conversely, smaller PAHs are more soluble and will be bio-available to biota through presence in pore water (AbdelShafy and Mansour 2016). PAH degradation into smaller ringed structures allows them to become either bio-available or become part of the pore water matrix and becoming adsorbed onto colloidal organic matter and accumulate in sediment concentrations (Abdel-Shafy and Mansour 2016; Jelena and Maja 2017). Furthermore, their bioavailability can also be dictated according to source and PAH species, e.g., PAHs from oil spills are more available in comparison with those from coal (Wang et al. 2014).

Their environmental behaviour and toxic effects have made them priority substances according to the water framework directive (WFD) (Nikolaou et al. 2009), but effects are PAH specific. For example, benzo[a]pyrene, originally isolated from coal tar in the 1930s, has been linked with carcinogenic properties and been linked to lung cancer (Kasala et al. 2015). Research also shows that certain PAH metabolites can interact with DNA and are genotoxic causing negative and heritable genetic damage (Agency for Toxic Substances and Disease Registry 2012). Some have also been highlighted with potentially carcinogenic properties, e.g., benzo[a]anthracene, chrysene, benzo[b]fluoranthene, benzo[a]pyrene and benzo[g,h,i]perylene.

The source identification of PAHs in sedimentary environments has proven difficult to determine, as the individual compounds cannot easily be distinguished from natural or anthropogenic sources. Typically PAH markers (Stogiannidis and Laane 2015), PAH-ratio methods (Yan et al. 2009), multivariate analysis (Jang et al. 2013) or isotope ratio mass spectrometry (Philp 2007) have been used with the potential to relate to historical industrial pollution (Ma et al. 2016).

\section{Sediment microbiome}

The co-discipline of sediment microbiology is concerned with microscopic and macroscopic organisms, including bacteria, protozoa, fungus, algae and soil-dwelling invertebrates (mesofauna) (Paul and Clark 1989) dwelling in sediments down to $2 \mathrm{~m}$ (Table 2). Microbial communities are found in habitats as diverse as environmental systems (the microbiome) in the human body, and often with similar interspecies interaction relationships (Drissi et al. 1995). This causes increased concerns that this can become linked to the increased spread and evolution of AMR in the microbiome.

Bacteria form the majority of sediment biomass and are well suited to a sedimentary environment as their size, metabolic versatility, and their collectively diverse nutrient and redox capabilities allow them to flourish in equally

Table 2 Variation of microorganism biomass with sediment depths and percentage decrease from surface adapted from (Bhattarai et al. 2015; Fierer et al. 2003)

\begin{tabular}{lll}
\hline Depth $(\mathrm{cm})$ & $\begin{array}{l}\text { Microorganism biomass }(\mathrm{g} / \\
\left.\mathrm{m}^{2}\right)\end{array}$ & $\%$ decrease \\
\hline $0-5$ & $9.8(1.6)$ & \\
$5-15$ & $4.0(0.16)$ & 59.18 \\
$15-25$ & $2.0(0.12)$ & 79.59 \\
50 & $0.63(0.044)$ & 93.57 \\
100 & $0.18(0.030)$ & 98.16 \\
200 & $0.081(0.0053)$ & 99.17 \\
\hline
\end{tabular}

Stratified layers of sediments accumulated over a reasonably long period of time, which can be cut in a series of successively receding flat surfaces (Velde and Barre 2010) 
diverse environments (Nealson 1997). Numerous conditions affect the presence and quantity of microbial communities (including those species with antimicrobial resistant genes (ARGs) present), and the knowledge of expected key community characteristics can be linked to their responses to physicochemical properties (e.g., conductivity (EC), $\mathrm{pH}$ and redox), nutritional quality (e.g., total nitrogen, phosphorus, carbon and minerals), source of carbon-including organic matter (Wang et al. 2016) — and pollutant conditions (including PTE and PAH content) of sediments (Fig. 1). This can create extreme spatial differences of species composition and community structures (Abd-El-Aziz et al. 2017). Fortunately, the advent of community DNA extractions and highthroughput sequencing has provided wealth of information related to this through metagenomics, whether targeted (e.g., via small sub-unit rRNA or specific genes) or "shot gun" (i.e., random).
The communities (and their potential to "share" or horizontally transfer genetic traits-discussed later) are shaped biologically by their ecological interactions. However, the make-up of the microbiome and its functional complexity can be likely influenced by legacy exposures. Like chemical conditions, they too can be archived in the sediment layers. What we will demonstrate is that past stress events, in turn, can have a major impact on the microbiome, but also the resistome-the collection of genes/traits related to resistance, whether latent or active.

\section{Development of antimicrobial resistance}

Evolutionary processes have recently been linked with the accumulation of antimicrobial resistance, which include the accumulation and selection of genetic mutations

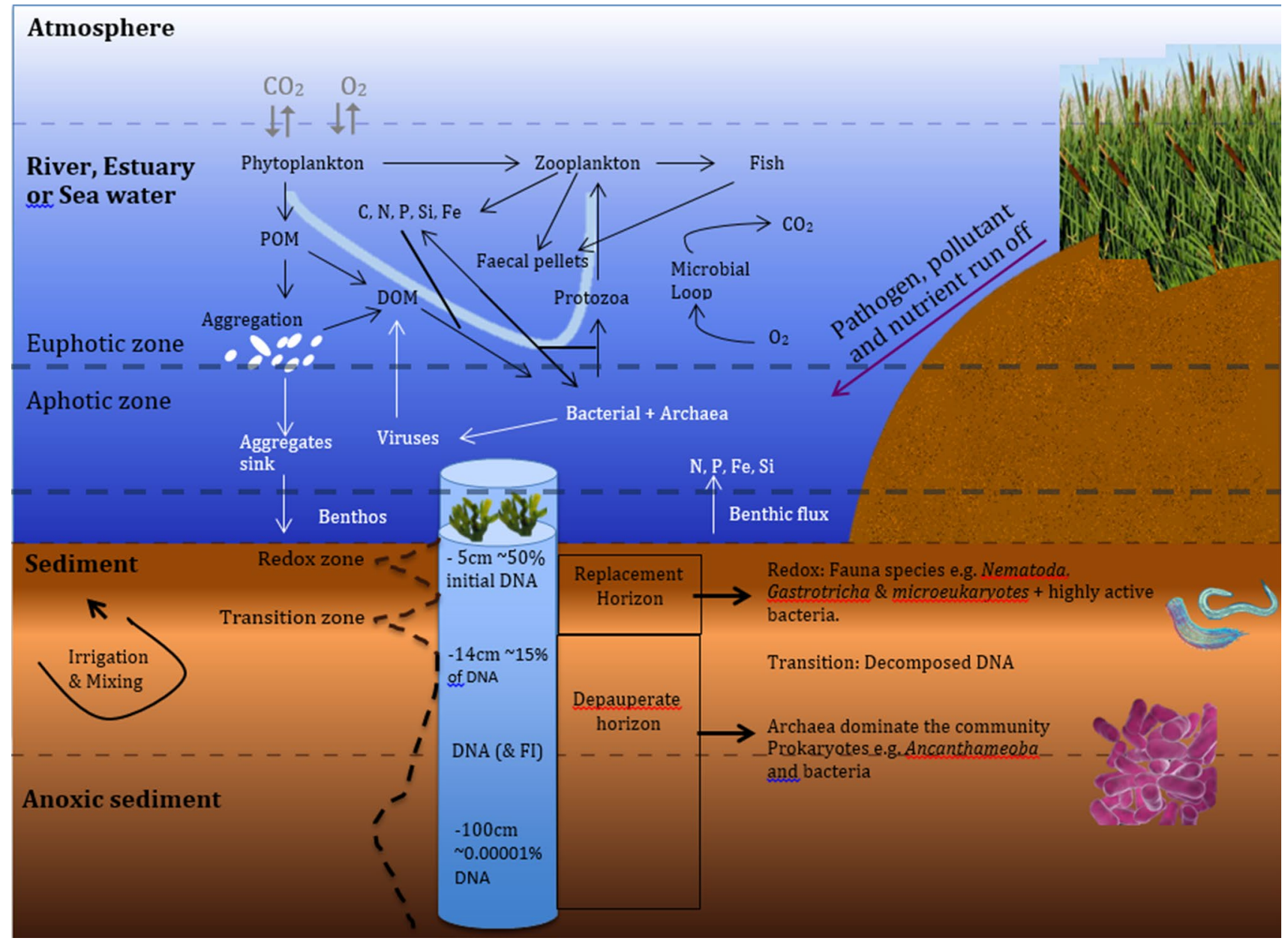

Fig. 1 Microbial structuring of an estuary sediment. Dissolved organic matter is almost exclusively taken up by bacteria and respired as $\mathrm{CO}_{2}$ or re-introduced into the classical food chain (phytoplankton, zooplankton and fish). This, in turn, alters the carbon cycle that influences the microbiome as well as sediment horizons. The redox-strat- ified zone $(0-5 \mathrm{~cm})$ includes a thin layer of oxygen where a few fauna species exist and microeukaryotes in addition to large numbers of highly active bacteria. Below $5 \mathrm{~cm}$ is the transition zone; here $50 \%$ of the DNA has already decomposed and is found below the sulphatemethane transition 


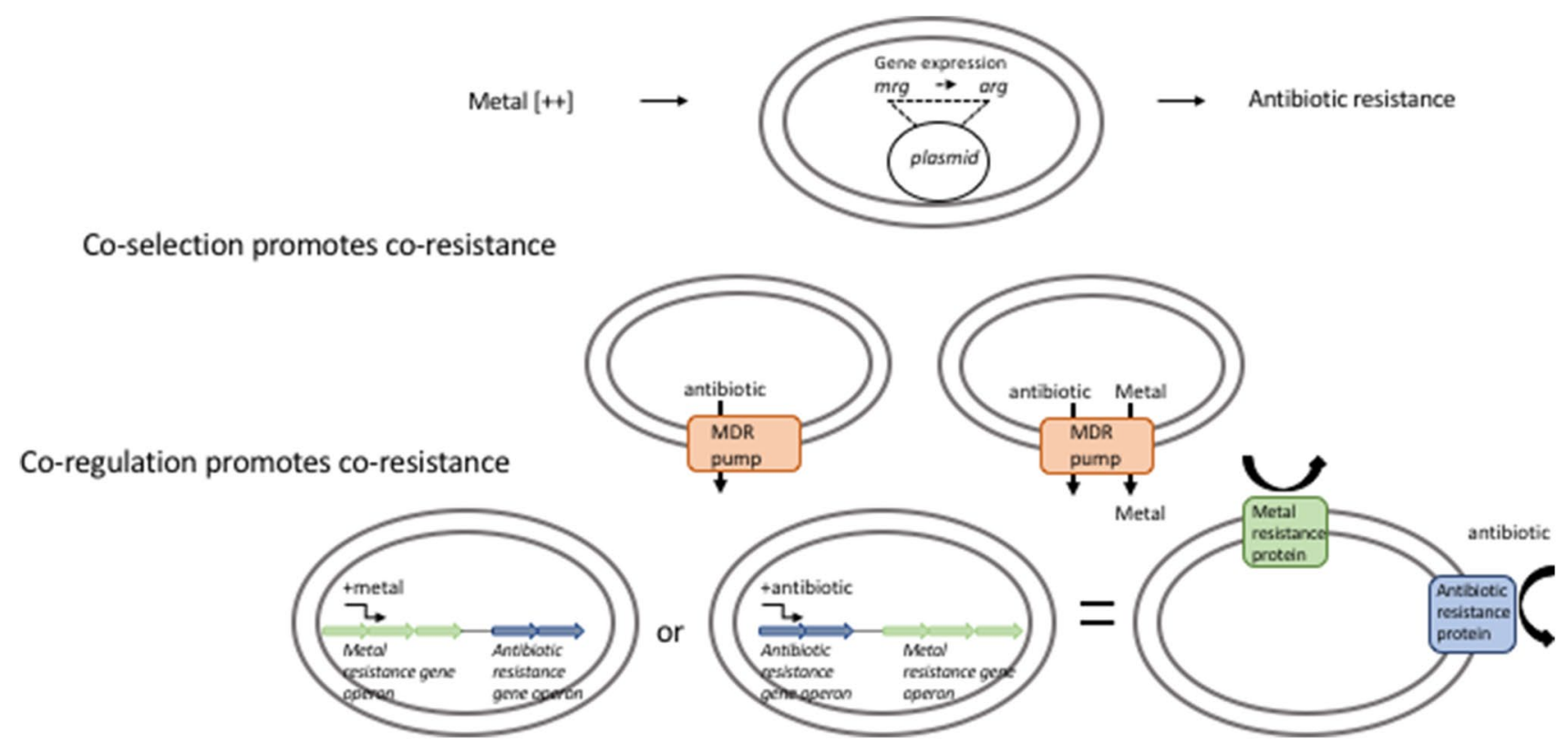

Fig. 2 Hypothesised molecular mechanisms that can result in AMR when antibiotics and metals are introduced into a biochemical system: "Co-selection". Mechanisms such as cross-resistance, co- resistance or co-regulatory resistance can result in AMRs prevalence (adapted from Baker-Austin et al. 2006; Mata et al. 2000)

However, in many microbial communities (e.g., biofilms) the close proximity of bacteria to each other, genetic material can also become horizontally exchanged among different population by various mechanisms (Fig. 2):

- Transformation - the assimilation of free DNA, released from lysed bacteria.

- Transduction-i.e., bacterial phages (viruses) acquire pieces of host DNA and transfer it to the next infected bacterial cell.

- Conjugation-the direct exchange of plasmid DNA.

The increase in ARGs occurs as a consequence of its ability to spread, via transformation or conjugation, between bacteria under antimicrobial stresses (Cottell et al. 2014; Turner et al. 2014); this a nature of many bacteria as part of their SOS response to stress (Beaber et al. 2004). Furthermore the "mobile resistome/mobilome", i.e., the ability for resistant genes to associate and transfer between distantly related bacteria (Wellington et al. 2013) exacerbates ARG presence in environmental matrices and has become a greater focus among current environmental-AMR research, as a potential target for the transfer of resistance traits could be a pathogen.

The determination of antibiotic resistance through identification of antibiotic resistance genes (ARGs) has provided evidence that ARGs have been increasing in environmental systems experiencing anthropogenic stress, e.g., soils, water and sediments in particular since the beginning of the 
antibiotic era in 1940s (Chen et al. 2013; Knapp et al. 2010; Graham et al. 2016). The most common entry routes for ARGs in the environment are from sewage outfall (Daughton and Ternes 1999), agricultural fertilisers (Kinney et al. 2006) and veterinary pressures (Blackwell et al. 2007; Topp et al. 2008). The increasing prevalence of AMR/ARG in the "real world" suggests an emerging global human health concern; it is reported that by 2050 global annual mortality is projected to be 10 million if action is not immediately taken to combat antimicrobial resistance (Shallcross et al. 2015).

\section{Role of pollution on resistant genes/AMR}

The environmental contribution to the spread of AMR is becoming more commonly recognised, and regulators are beginning to monitor pathways and controlling the release of resistant-driving chemicals, e.g., antimicrobials, metals and biocides (Singer et al. 2016). A common type of resistance that has become a contemporary concern is resistance to antibiotics, but it has recently been observed is that other substances can also select for antibiotic resistance. For example, metal pollution and some persistent organic compounds co-select for antibiotic resistance genes. This co-selection of metal (or other) resistance and antibiotic resistance can occur by one of two processes: co-resistance or cross-resistance. Co-resistance occurs when selection of one phenotype simultaneously selects for genes on the same genetic element. On the other hand, cross-resistance occurs when, for example, the antibiotic and metal have similar paths into the cell, therefore when a resistance response is triggered, cell defence is effective against both metal and antibiotic toxicants. Since metals, e.g., are also widespread in the environment (and probably in elevated concentration in zones of industrial activity) and do not degrade, these toxicants can potentially provide a long-term selection pressure.

Like soils, sediments are considered a reservoir of antibiotic resistance bacteria (Azarbad et al.) and ARGs, with a large variety of novel ARGs and RGs being frequently discovered-representing different types of resistance mechanisms (Nesme and Simonet, 2015), and there are anthropogenic pressures that can exacerbate this. Sources of ARB (and ARG) include the discharge of improperly treated municipal wastewater treatment effluents, agricultural runoff, and wildlife. The bacteria entering the waterways could become bound, and eventually entombed, in the sediments and contributing to the resistome "potential".

However, estuarine systems offer additional complications. Due to the continual changes in salinity, estuarine biota are subject to naturally stressful conditions and become more susceptible to stress from anthropogenic pollution. With the sediments acting as both a sink and source of pollutants, also switching between absorption and desorption reactions due to alternating salinity changes (Chapman and Wang 2001), indigenous bacteria repeatedly become exposed to contaminants. Consequently, they develop survival strategies for stress, including the enhanced transfer of mobile genetic elements. The unfortunate result is these genetic exchanges could include antimicrobial resistance (AMR).

Elevated antibiotic resistance (AR) is evident in environments with high levels of anthropogenic stress (Chen et al. 2013; Knapp et al. 2010) which challenges the common perception that AMR solely occurs as a consequence of antibiotics. A study along the Almendares River/estuary, Cuba demonstrated a high level of resistant genes present despite minimal use of antibiotics, both agriculturally and medically in the country; there were, however, high levels of pollution including metals and other contaminants (Graham et al. 2011; Reid-Henry 2008). Unfortunately, efforts to reduce and control antibiotic use may have limited impact on AR if antibiotics are not the sole cause of AMR in environments.

\section{PTEs and AMR}

PTEs within environmental matrices impact microbial communities and represent important vector in the maintenance and proliferation of AMR (Summers 2002; Alonso et al. 2001; Eldon and Smith 2006). The synergistic effects of PTEs and antibiotics have also been shown to influence the development of AMR (Chen et al. 2015; Baker-Austin et al. 2006). For example, the co-exposure to $\mathrm{Zn}$ and oxytetracycline increases the microbial community's resistance towards antibiotics (Peltier et al. 2010; Besta et al. 2013). Further the presence of $\mathrm{Cu}$ caused microbial resilience, as well as a co-resistance, to ampicillin, chloramphenicol and tetracycline (Berg et al. 2005; Mccluskey and Knapp 2017). Additionally, $\mathrm{Ni}$ and $\mathrm{Cd}$ have increased the frequency of bacterial resistance in microcosms to chemically unrelated antibiotics including ampicillin and chloramphenicol (Stepanauskas et al. 2006). This suggests that (1) the proliferation of antibiotic resistance can be caused by the presence of PTEs enhancing the enrichment of ARG in indigenous bacterial growth in the microbial communities where ARGs are already present (Chen et al. 2015) or (2) that resistance occurs only in bacteria sensitive to antibiotics which in turn could be induced by synergistic effects of the co-existence of PTEs (Zhu et al. 2013).

PTEs such as $\mathrm{Zn}, \mathrm{Cu}, \mathrm{Mn}, \mathrm{Ni}, \mathrm{Cr}$ and $\mathrm{Fe}$ are essential nutrients for micro-organisms (Lima De Silva et al. 2012) and provide vital co-factors for metallo-proteins and enzymes; however, once concentrations exceed "ideal" levels, PTEs inhibit bacteria by blocking the essential functional sites (Koena Sinah 2005)—whereby metal ions become displaced from their "native" binding site, causing conformation modifications of the molecules (Olaniran et al. 2013). Besides diminished enzyme function, some 
could damage DNA. PTEs with no biological role, e.g., $\mathrm{Pb}$ and $\mathrm{Cd}$, can cause oxidative stress, lipid peroxidation and mutagenesis (Oyetibo et al. 2010). Further, $\mathrm{Cu}$ and $\mathrm{Zn}$ are also commonly used antimicrobials (Poole 2017).

Hypothesised mechanisms for metal resistance include PTE accumulation in the form of protein-metal associations, blockages at the level of the cell walls, and enhanced membrane transportation (Hassen et al. 1998), sorption of metals (Chang et al. 1993; Kinkle et al. 1987), and release of organic chelators (Abd-El-Aziz et al. 2017; Lemire et al. 2013). The processes are complex, which are in-turn controlled by a vast variety of variables including, but not limited to PTE presence, nature of environmental medium and/ or the microbial species. A number of potential mechanisms causing the increase in ARGs in the presence of PTEs have been evidenced, including in areas resulting from intense industrial activity (Abella et al. 2015; Graham et al. 2011; Hu et al. 2016; Knapp et al. 2012; Stepanauskas et al. 2005; Wright et al. 2006), wastewater treatment outflows (Knapp et al. 2012; Graham et al. 2011; Su et al. 2015), run-off of agricultural wastes (Ji et al. 2012; Li et al. 2015b; Zhu et al. 2013) and direct experiments (Berg et al. 2005, 2010; Knapp et al. 2011; Stepanauskas et al. 2006).

While most evidence is found in areas of elevated human impact, correlations have been found in more "pristine", or baseline environmental levels, as well (Knapp et al. 2011, 2017). The driving force (as mentioned previously) is believed to result from co- and cross-selection processes (Ashbolt et al. 2013; Baker-Austin et al. 2006; Berg et al. 2010; Perry and Wright 2013). Many resistance elements may co-exist on a single genetic element, or bacteria will seek improved resistance traits via lateral gene transfer mechanisms and receive the additional traits. Given that metals do not degrade; selective pressures are likely to persist longer than pharmaceutical compounds which could breakdown in the environment.

\section{PAHs and AMR}

Microbial degradation has an important role in the natural attenuation of PAHs in contaminated matrices (Van Dillewijn et al. 2009); however, the presence of PAHs changes the community structure of indigenous bacteria with the number of hydrocarbon-degrading bacteria increases with increasing available hydrocarbons (De Menezes et al. 2012; Zhang et al. 2010; Maila et al. 2005); it is difficult to understand which communities are present in historically contaminated sediments (Azarbad et al. 2016; Singleton et al. 2013). However, many PAH-tolerant bacterial isolates often exhibit strong resistance to metals and antibiotics (Ben Said et al. 2008; Máthé et al. 2012), and ARGs have been found in PAH-contaminated matrices (Chen et al. 2017; Kang et al. 2015).

PAHs have mutagenic properties (Liu et al. 2017; Sun et al. 2015), which could contribute towards AMR-either by directly changing DNA composition, or triggering stress/repair systems. There is little knowledge of specific mechanisms, but metagenomic profiling has demonstrated that PAH-contaminated soils with ARGs is in abundance approximately 15 times more than those less contaminated (Chen et al. 2017).

In comparison with the number of investigations conducted examining other drivers of antimicrobial resistance (e.g., pharmaceutic compounds and PTEs), there have been relatively minimal studies on the effects of PAH contamination to AMR, and few prediction models exist. However, research has demonstrated that naphthalene and phenanthrene exposure were primarily linked to conjugative transfer of genes mediated by class I integrons (Wang et al. 2017); these genetic mechanisms allow bacteria to adapt and evolve rapidly through the acquisition, stockpiling and differential expression of new genes and have been previously correlated with clinical antibiotic resistance (Gillings et al. 2008; Deng et al. 2015; Loot et al. 2017). Genes for PTEs and ARGs have been found in bacterial plasmids and could facilitate the dissemination of these genes under elevated stresses ( $\mathrm{Li}$ et al. 2015a; Zhai et al. 2016). The effect of the co-exposure is complicated; however, (Lu et al. 2014) found that a moderate dosage of pyrene promotes the microbial prosperity in soils and alleviating metal stress. Previous studies have investigated and shown a co-exposure effect with PAHs and metals which is a consequence of increased anthropogenic activities and contamination; this includes the research of (Gauthier et al. 2014) who summarised that the more-than-additive deleterious effects of PAHs-metal mixtures to microbes.

\section{Conclusion}

The genetically diverse array of micro-organisms with their respective metabolisms, as well as the complex array of environmental pollutants, i.e., PTEs, PAHs and their derivatives, makes understanding their combined roles in induced antimicrobial resistance a complicated task. This review highlights that PTEs and PAHs create stressful conditions to exacerbate AMR in the environment and can be used as model pollutants for further public-health risks related to these genetic pollutants. The effects are not just related to current pollution scenarios; rather, legacy industrial effects could be lingering drivers for resistance. The combined effect of various single and multiple mechanisms can be hypothesised to explain the genetic mutation and development of AMR; however, further exploration is required to 
elucidate a more causal explanation. No antimicrobial agent will be efficacious forever; however, by establishing a better understanding of the environmental impact and its role in AMR's prevalence may aid in its control. This is critical to combat AMR growth and prevalence across the world, with a target on the prospects for prevention, treatment or remediation.

Acknowledgements The author's wish to acknowledge NERC for their Antimicrobial resistance in the real-world funding call NE/NO1474/1.

Open Access This article is distributed under the terms of the Creative Commons Attribution 4.0 International License (http://creativeco mmons.org/licenses/by/4.0/), which permits unrestricted use, distribution, and reproduction in any medium, provided you give appropriate credit to the original author(s) and the source, provide a link to the Creative Commons license, and indicate if changes were made.

\section{References}

Abd-El-Aziz AS, Agatemor C, Etkin N (2017) Antimicrobial resistance challenged with metal-based antimicrobial macromolecules. Biomaterials 118:27-50

Abdel-Shafy HI, Mansour MSM (2016) A review on polycyclic aromatic hydrocarbons: source, environmental impact, effect on human health and remediation. Egypt J Pet 25:107-123

Abella J, Fahy A, Duran R, Cagnon C (2015) Integron diversity in bacterial communities of freshwater sediments at different contamination levels. FEMS Microbiol Ecol 91(12):1-11. https:// doi.org/10.1093/femsec/fiv140

Agency for Toxic Substances and Disease Registry (2012) Case studies in environmental medicine: toxicity of polycyclic aromatic hydrocarbons (PAHs)

Akcil A, Erust C, Ozdemiroglu S, Fonti V, Beolchini F (2015) A review of approaches and techniques used in aquatic contaminated sediments: metal removal and stabilization by chemical and biotechnological processes. J Clean Prod 86:24-36

Alonso A, Sanchez P, Martinez JL (2001) Environmental selection of antibiotic resistance genes. Environ Microbiol 3:1-9

Ashbolt NJ, Amézquita A, Backhaus T, Borriello P, Brandt KK, Collignon P, Coors A, Finley R, Gaze WH, Heberer T, Lawrence JR, Larsson DGJ, Mcewen SA, Ryan JJ, Schönfeld J, Silley P, Snape JR, Van Den Eede C, Topp E (2013) Human health risk assessment (HHRA) for environmental development and transfer of antibiotic resistance. Environ Health Perspect 121:993-1001

Atsdr (2005) CERCLA priority list of hazardous substances. US Department of Health and Human Service, Atlanta

Azarbad H, Van Gestel CaM, Niklińska M, Laskowski R, Röling WFM, Van Straalen NM (2016) Resilience of soil microbial communities to metals and additional stressors: DNA-based approaches for assessing "stress-on-stress" responses. Int J Mol Sci 17:933

Baker-Austin C, Wright MS, Stepanauskas R, Mcarthur JV (2006) Coselection of antibiotic and metal resistance. Trends Microbiol $14: 176-182$

Beaber JW, Hochhut B, Waldor MK (2004) SOS response promotes horizontal dissemination of antibiotic resistance genes. Nature 427:72-74

Ben Said O, Goni-Urriza MS, El Bour M, Dellali M, Aissa P, Duran $\mathrm{R}$ (2008) Characterization of aerobic polycyclic aromatic hydrocarbon-degrading bacteria from Bizerte lagoon sediments, Tunisia. J Appl Microbiol 104:987-997

Berg J, Tom-Petersen A, Nybroe O (2005) Copper amendment of agricultural soil selects for bacterial antibiotic resistance in the field. Lett Appl Microbiol 40:146-151

Berg J, Thorsen MK, Holm PE, Jensen J, Nybroe O, Brandt KK (2010) $\mathrm{Cu}$ exposure under field conditions coselects for antibiotic resistance as determined by a novel cultivation-independent bacterial community tolerance assay. Environ Sci Technol 44:8724-8728

Berner EK, Berner RA (2012) Global environment water, air, and geochemical cycles (2nd edn). Princeton University Press, New Jersey

Bernier SP, Surette MG (2013) Concentration-dependent activity of antibiotics in natural environments. Front Microbiol 4:20

Besta P, Janovská K, Samolejová A, Beránková A, Vozňáková I, Hendrych M (2013) The cycle and effect of zinc in the blast-furnace process. Metalurgija 52:197-200

Bhattarai A, Bhattarai B, Pandey S (2015) Variation of soil microbial population in different soil horizons. Microbiol Exp 2(2):1-4

Birch GF, Gunns TJ, Olmos M (2015) Sediment-bound metals as indicators of anthropogenic change in estuarine environments. Mar Pollut Bull 101:243-257

Blackwell PA, Kay P, Boxall ABA (2007) The dissipation and transport of veterinary antibiotics in a sandy loam soil. Chemosphere 67:292-299

Bosch C, Andersson A, Kruså M, Bandh C, Hovorková I, Klánová J, Knowles TDJ, Pancost RD, Evershed RP, Gustafsson Ö (2015) Source apportionment of polycyclic aromatic hydrocarbons in central european soils with compound-specific triple isotopes ( $\delta 13 \mathrm{C}, \Delta 14 \mathrm{C}$, and $\delta 2 \mathrm{H})$. Environ Sci Technol 49:7657-7665

Caccia VG, Millero FJ, Palanques A (2003) The distribution of trace metals in Florida Bay sediments. Mar Pollut Bull 46:1420-1433

Chang J-S, Hong J, Ogunseitan OA, Olson BH (1993) Interaction of Mercuric Ions with the Bacterial Growth Medium and Its Effects on Enzymatic Reduction of Mercury. Biotechnol Prog 9(5):526532. https://doi.org/10.1021/bp00023a012

Chapman PM, Wang F (2001) Assessing sediment contamination in estuaries. Environ Toxicol Chem 20:3-22

Chen B, Liang X, Huang X, Zhang T, Li X (2013) Differentiating anthropogenic impacts on ARGs in the Pearl River Estuary by using suitable gene indicators. Water Res 47:2811-2820

Chen S, Li X, Sun G, Zhang Y, Su J, Ye J (2015) Heavy metal induced antibiotic resistance in bacterium LSJC7. Int J Mol Sci 16:23390-23404

Chen B, He R, Yuan K, Chen E, Lin L, Chen X, Sha S, Zhong J, Lin L, Yang L, Yang Y, Wang X, Zou S, Luan T (2017) Polycyclic aromatic hydrocarbons (PAHs) enriching antibiotic resistance genes (ARGs) in the soils. Environ Pollut 220, Part B, 1005-1013

Choi Y, Cho Y-M, Gala WR, Luthy RG (2013) Measurement and modeling of activated carbon performance for the sequestration of parent- and alkylated-polycyclic aromatic hydrocarbons in petroleum-impacted sediments. Environ Sci Technol 47:1024-1032

Cottell JL, Saw HT, Webber MA, Piddock LJ (2014) Functional genomics to identify the factors contributing to successful persistence and global spread of an antibiotic resistance plasmid. BMC Microbiol 14:168

Cuculić V, Cukrov N, Kwokal Ž, Mlakar M (2009) Natural and anthropogenic sources of $\mathrm{Hg}, \mathrm{Cd}, \mathrm{Pb}, \mathrm{Cu}$ and $\mathrm{Zn}$ in seawater and sediment of Mljet National Park, Croatia. Estuar Coast Shelf Sci 81:311-320

Curtosi A, Pelletier E, Vodopivez CL, Mac Cormack WP (2007) Polycyclic aromatic hydrocarbons in soil and surface marine sediment near Jubany Station (Antarctica). Role of permafrost as a lowpermeability barrier. Sci Total Environ 383:193-204 
Daughton CG, Ternes TA (1999) Pharmaceuticals and personal care products in the environment: agents of subtle change? Environ Health Perspect 107:907-938

De Menezes A, Clipson N, Doyle E (2012) Comparative metatranscriptomics reveals widespread community responses during phenanthrene degradation in soil. Environ Microbiol 14:2577-2588

Deng Y, Bao X, Ji L, Chen L, Liu J, Miao J, Chen D, Bian H, Li Y, Yu G (2015) Resistance integrons: class 1, 2 and 3 integrons. Ann Clin Microbiol Antimicrob 14:45

Drissi SH, Refait P, Abdelmoula M, Génin JMR (1995) The preparation and thermodynamic properties of $\mathrm{Fe}(\mathrm{II}), \mathrm{Fe}(\mathrm{III})$ hydroxidecarbonate (green rust 1); Pourbaix diagram of iron in carbonatecontaining aqueous media. Corros Sci 37:2025-2041

Edgar PJ, Davies IM, Hursthouse AS, Matthews JE (1999) The Biogeochemistry of Polychlorinated Biphenyls (PCBs) in the Clyde: Distribution and Source Evaluation. Marine Pollution Bulletin 38(6):486-496. https://doi.org/10.1016/S0025-326X(98)00177-5

Edgar PJ, Hursthouse AS, Matthews JE, Davies IM (2003) An investigation of geochemical factors controlling the distribution of PCBs in intertidal sediments at a contamination hot spot, the Clyde Estuary, UK. Applied Geochemistry 18(2):327-338. https ://doi.org/10.1016/S0883-2927(02)00128-2

Edgar PJ, Hursthouse AS, Matthews JE, Davies IM, Hillier S (2006) Sediment influence on congener-specific PCB bioaccumulation by Mytilus edulis: a case study from an intertidal hot spot, Clyde Estuary, UK. J Environ Monit 8(9):887-896. https://doi. org/10.1039/b606960f

Eggleton J, Thomas KV (2004) A review of factors affecting the release and bioavailability of contaminants during sediment disturbance events. Environ Int 30:973-980

Eldon E, Smith B (2006) Environmental science: a study of interrelationships. McGraw Hill Press, New York

European Centre for Disease Prevention and Control. 2014. Antibiotic resistance: how does antibiotic resistance spread? https ://ecdc.europa.eu/sites/portal/files/images/how-does-antibiotic -resistance-spread.jpg. Accessed June 2017

Farmer JG (1991) The perturbation of historical pollution records in aquatic sediments. Environ Geochem Health 13:76-83

Fierer N, Schimel JP, Holden PA (2003) Variations in microbial community composition through two soil depth profiles. Soil Biol Biochem 35:167-176

Friedlingstein P, Cox P, Betts R, Bopp L, Von Bloh W, Brovkin V, Cadule P, Doney S, Eby M, Fung I, Bala G, John J, Jones C, Joos F, Kato T, Kawamiya M, Knorr W, Lindsay K, Matthews HD, Raddatz T, Rayner P, Reick C, Roeckner E, Schnitzler KG, Schnur R, Strassmann K, Weaver AJ, Yoshikawa C, Zeng N (2006) Climate-carbon cycle feedback analysis: results from the C4MIP model intercomparison. J Clim 19:3337-3353

Gauthier PT, Norwood WP, Prepas EE, Pyle GG (2014) Metal-PAH mixtures in the aquatic environment: a review of co-toxic mechanisms leading to more-than-additive outcomes. Aquat Toxicol 154:253-269

Gillings M, Boucher Y, Labbate M, Holmes A, Krishnan S, Holley M, Stokes HW (2008) The evolution of class 1 integrons and the rise of antibiotic resistance. J Bacteriol 190:5095-5100

Graham DW, Olivares-Rieumont S, Knapp CW, Lima L, Werner D, Bowen E (2011) Antibiotic resistance gene abundances associated with waste discharges to the Almendares River near Havana, Cuba. Environ Sci Technol 45:418-424

Graham DW, Knapp CW, Christensen BT, Mccluskey S, Dolfing J (2016) Appearance of $\beta$-lactam resistance genes in agricultural soils and clinical isolates over the 20th Century. Sci Rep $6: 21550$

Haftka J (2009) Bioavailability of polycyclic aromatic hydrocarbons in sediments: experiments and modelling. Ph.D, University of Amsterdam
Hassen A, Saidi N, Cherif M, Boudabous A (1998) Resistance of environmental bacteria to heavy metals. Biores Technol 64:7-15

Hu HW, Wang JT, Li J, Li JJ, Ma YB, Chen D, He JZ (2016) Fieldbased evidence for copper contamination induced changes of antibiotic resistance in agricultural soils. Environ Microbiol 18:3896-3909

Hursthouse AS, Adamczyk M, Adamczyk L, Smith FJ, Iqbal P (1994) Inorganic and organic contaminants in intertidal sediments of the Clyde: preliminary observations of historic trends. Mar Pollut Bull 28:765-767

Huston R, Chan YC, Gardner T, Shaw G, Chapman H (2009) Characterisation of atmospheric deposition as a source of contaminants in urban rainwater tanks. Water Res 43:1630-1640

Jang E, Alam MS, Harrison RM (2013) Source apportionment of polycyclic aromatic hydrocarbons in urban air using positive matrix factorization and spatial distribution analysis. Atmos Environ 79:271-285

Jaward FM, Alegria HA, Galindo Reyes JG, Hoare A (2012) Levels of PAHs in the waters, sediments, and shrimps of Estero de Urias, an Estuary in Mexico, and their toxicological effects. Sci World J 2012:9

Jelena M, Maja PV (2017) Concentrations and origin of polycyclic aromatic hydrocarbons in sediments of the Middle Adriatic Sea Acta Adriat Int J Mar Sci 58:3-23

Ji X, Shen Q, Liu F, Ma J, Xu G, Wang Y, Wu M (2012) Antibiotic resistance gene abundances associated with antibiotics and heavy metals in animal manures and agricultural soils adjacent to feedlots in Shanghai; China. J Hazard Mater 235-236:178-185

Jordi, A. 2016. Traces of history in the sediments of Lake Joux. EAWAG aquatic research. http://www.eawag.ch/en/news-agend a/news-portal/news-detail/news/spuren-der-geschichte-im-lacde-joux/. Accessed 2017

Kafilzadeh F (2015) Distribution and sources of polycyclic aromatic hydrocarbons in water and sediments of the Soltan Abad River, Iran. Egypt J Aquat Res 41:227-231

Kang F, Hu X, Liu J, Gao Y (2015) Noncovalent binding of polycyclic aromatic hydrocarbons with genetic bases reducing the in vitro lateral transfer of antibiotic resistant genes. Environ Sci Technol 49:10340-10348

Kasala ER, Bodduluru LN, Barua CC, Sriram CS, Gogoi R (2015) Benzo(a)pyrene induced lung cancer: role of dietary phytochemicals in chemoprevention. Pharmacol Rep 67:996-1009

Ke L, Yu KSH, Wong YS, Tam NFY (2005) Spatial and vertical distribution of polycyclic aromatic hydrocarbons in mangrove sediments. Sci Total Environ 340:177-187

Khan MZH, Hasan MR, Khan M, Aktar S, Fatema K (2017) Distribution of heavy metals in surface sediments of the Bay of Bengal Coast. J Toxicol 2017:7

Kinkle BK, Angle JS, Keyser HH (1987) Long-Term Effects of Metal-Rich Sewage Sludge Application on Soil Populations of Bradyrhizobium japonicum. Appl Environ Microbiol 53(2):315-319

Kinney CA, Furlong ET, Zaugg SD, Burkhardt MR, Werner SL, Cahill JD, Jorgensen GR (2006) Survey of organic wastewater contaminants in biosolids destined for land application. Environ Sci Technol 40:7207-7215

Knapp CW, Dolfing J, Ehlert PaI, Graham DW (2010) Evidence of increasing antibiotic resistance gene abundances in archived soils since 1940. Environ Sci Technol 44:580-587

Knapp CW, Mccluskey SM, Singh BK, Campbell CD, Hudson G, Graham DW (2011) Antibiotic resistance gene abundances correlate with metal and geochemical conditions in archived Scottish soils. PLoS ONE 6:e27300

Knapp CW, Lima L, Olivares-Rieumont S, Bowen E, Werner D, Graham DW (2012) Seasonal variations in antibiotic resistance 
gene transport in the Almendares River, Havana, Cuba. Front Microbiol 3:396

Knapp CW, Callan AC, Aitken B, Shearn R, Koenders A, Hinwood A (2017) Relationship between antibiotic resistance genes and metals in residential soil samples from Western Australia. Environ Sci Pollut Res 24:2484-2494

Koena Sinah S (2005) Heavy metals ion resistance and biorememdiation capacties of bacterial strains isolated from an antimony mine. Masters, University of Limpopo

Konhausera KO, Mortimer RJG, Morris K, Dunn V (2002). Chapter 3 The role of microorganisms during sediment diagenesis: implications for radionuclide mobility. In: Keith-Roach MJ, Livens FR (eds.) Radioactivity in the environment. Elsevier

Larrose A, Coynel A, Schäfer J, Blanc G, Massé L, Maneux E (2010) Assessing the current state of the Gironde Estuary by mapping priority contaminant distribution and risk potential in surface sediment. Appl Geochem 25:1912-1923

Larsson DGJ (2014) Pollution from drug manufacturing: review and perspectives. Philos Trans R Soc B Biol Sci 369:20130571

Legorburu I, Rodríguez JG, Borja Á, Menchaca I, Solaun O, Valencia V, Galparsoro I, Larreta J (2013) Source characterization and spatio-temporal evolution of the metal pollution in the sediments of the Basque estuaries (Bay of Biscay). Mar Pollut Bull 66:25-38

Lemire JA, Harrison JJ, Turner RJ (2013) Antimicrobial activity of metals: mechanisms, molecular targets and applications. Nat Rev Microbiol 11:371-384

Lenart-Boroń A, Boroń P (2014) The Effect of Industrial Heavy Metal Pollution on Microbial Abundance and Diversity in Soils-a Review. In: Hernandez-Soriano MC (ed.) Environmental risk assessment of soil contamination. InTech, Rijeka

Li C-H, Zhou H-W, Wong Y-S, Tam NF-Y (2009) Vertical distribution and anaerobic biodegradation of polycyclic aromatic hydrocarbons in mangrove sediments in Hong Kong, South China. Sci Total Environ 407:5772-5779

Li A-D, Li L-G, Zhang T (2015a) Exploring antibiotic resistance genes and metal resistance genes in plasmid metagenomes from wastewater treatment plants. Front Microbiol 6:1025

Li J, Ma YB, Hu HW, Wang JT, Liu YR, He JZ (2015b) Field-based evidence for consistent responses of bacterial communities to copper contamination in two contrasting agricultural soils. Front Microbiol 6:31

Lima De Silva AA, De Carvalho MaR, De Souza SaL, Dias PMT, Da Silva Filho RG, De Meirelles Saramago CS, De Melo Bento CA, Hofer E (2012) Heavy metal tolerance (Cr, Ag AND Hg) in bacteria isolated from sewage. Braz J Microbiol 43:1620-1631

Liu S-H, Zeng G-M, Niu Q-Y, Liu Y, Zhou L, Jiang L-H, Tan X-F, Xu P, Zhang C, Cheng M (2017) Bioremediation mechanisms of combined pollution of PAHs and heavy metals by bacteria and fungi: a mini review. Biores Technol 224:25-33

Loot C, Nivina A, Cury J, Escudero JA, Ducos-Galand M, Bikard D, Rocha EPC, Mazel D (2017) Differences in integron cassette excision dynamics shape a trade-off between evolvability and genetic capacitance. mBio 8: e02296-16

Lu M, Zhang ZZ, Wang JX, Zhang M, Xu YX, Wu XJ (2014) Interaction of heavy metals and pyrene on their fates in soil and tall fescue (Festuca arundinacea). Environ Sci Technol 48:1158-1165

Ma J, Zhang W, Chen Y, Zhang S, Feng Q, Hou H, Chen F (2016) Spatial variability of PAHs and microbial community structure in surrounding surficial soil of coal-fired power plants in Xuzhou. Int J Environ Res Public Health, China, p 13

Maila MP, Randima P, Surridge K, Drønen K, Cloete TE (2005) Evaluation of microbial diversity of different soil layers at a contaminated diesel site. Int Biodeterior Biodegrad 55:39-44
Martinez JL (2008) Antibiotics and antibiotic resistance genes in natural environments. Science 321(5887):365-367. https://doi. org/10.1126/science. 1159483

Mata MT, Baquero F, Pérez-DíAz JC (2000) A multidrug efflux transporter in Listeria monocytogenes. FEMS Microbiol Lett 187:185-188

Máthé I, Benedek T, Táncsics A, Palatinszky M, Lányi S, Márialigeti K (2012) Diversity, activity, antibiotic and heavy metal resistance of bacteria from petroleum hydrocarbon contaminated soils located in Harghita County (Romania). Int Biodeterior Biodegrad 73:41-49

McCluskey S, Knapp CW (2017) Selection of tetracycline and ampicillin resistance genes during long-term soil-copper exposure. In: Antibiotic resistance genes in natural environments and long-term effects. Nova Science Publishers Inc, New York, pp 199-216

Mclellan I, Hursthouse A, Varela A, Pereira CS (2013) Geochemical approach to assessing human impacts in Cork Oak forest soils of the MED region. J Geochem Explor 132:34-40

Monier JM, Demanèche S, Delmont TO, Mathieu A, Vogel TM, Simonet P (2011) Metagenomic exploration of antibiotic resistance in soil. Curr Opin Microbiol 14:229-235

Munita JM, Arias CA (2016) Mechanisms of antibiotic resistance. Microbiology spectrum 4. https://doi.org/10.1128/microbiols pec.VMBF-0016-2015

Nealson KH (1997) Sediment bacteria: who's there, what are they doing, and what's new? Ann Rev Earth Planet Sci 25:403-434

Nesme J, Simonet P (2015) The soil resistome: a critical review on antibiotic resistance origins, ecology and dissemination potential in telluric bacteria. Environ Microbiol 17:913-930

Nikolaou A, Kostopoulou M, Petsas A, Vagi M, Lofrano G, Meric S (2009) Levels and toxicity of polycyclic aromatic hydrocarbons in marine sediments. TrAC Trends Anal Chem 28:653-664

Oecd (2010) Environmental and climate change issues in the shipbuilding industry. In: Organisation for economic co-operation and development (ed.) OECD Council Working Party on Shipbuilding (WP6)

Olaniran AO, Balgobind A, Pillay B (2013) Bioavailability of heavy metals in soil: impact on microbial biodegradation of organic compounds and possible improvement strategies. Int J Mol Sci 14:10197-10228

Onozato M, Nishigaki A, Okoshi K (2016) Polycyclic aromatic hydrocarbons in sediments and bivalves on the Pacific Coast of Japan: influence of tsunami and fire. PLoS ONE 11:e0156447

Oyetibo GO, Ilori MO, Adebusoye SA, Obayori OS, Amund OO (2010) Bacteria with dual resistance to elevated concentrations of heavy metals and antibiotics in Nigerian contaminated systems. Environ Monit Assess 168:305-314

Palleiro L, Patinha C, Rodríguez-Blanco ML, Taboada-Castro MM, Taboada-Castro MT (2016) Metal fractionation in topsoils and bed sediments in the Mero River rural basin: bioavailability and relationship with soil and sediment properties. CATENA $144: 34-44$

Papaioannou D (2003) Environmental implications, related to the shipbuilding and ship repairing activity in Greece

Paul EA, Clark FE (1989) Soil microbiology and biochemistry. USA Harcourt Brace Jovanovich Publishers, San Dieago, CA

Pavlova A, Ivanova R (2003) Determination of petroleum hydrocarbons and polycyclic aromatic hydrocarbons in sludge from wastewater treatment basins. J Environ Monit 5:319-323

Peltier E, Vincent J, Finn C, Graham DW (2010) Zinc-induced antibiotic resistance in activated sludge bioreactors. Water Res 44:3829-3836

Peng JF, Song YH, Yuan P, Cui XY, Qiu GL (2009) The remediation of heavy metals contaminated sediment. J Hazard Mater 161(23):633-640. https://doi.org/10.1016/j.jhazmat.2008.04.061 
Perry JA, Wright GD (2013) The antibiotic resistance "mobilome": searching for the link between environment and clinic. Front Microbiol 4:138

Petit JCJ, Schäfer J, Coynel A, Blanc G, Chiffoleau J-F, Auger D, Bossy C, Derriennic H, Mikolaczyk M, Dutruch L, Mattielli $\mathrm{N}$ (2015) The estuarine geochemical reactivity of $\mathrm{Zn}$ isotopes and its relevance for the biomonitoring of anthropogenic $\mathrm{Zn}$ and Cd contaminations from metallurgical activities: example of the Gironde fluvial-estuarine system, France. Geochim Cosmochim Acta 170:108-125

Philp RP (2007) The emergence of stable isotopes in environmental and forensic geochemistry studies: a review. Environ Chem Lett 5:57-66

Poole K (2017) At the nexus of antibiotics and metals: the impact of $\mathrm{Cu}$ and $\mathrm{Zn}$ on antibiotic activity and resistance. Trends Microbiol $25: 820-832$

Reid-Henry S (2008) Scientific innovation and non-Western regional economies: Cuban biotechnology's 'experimental milieu'. Environ Plan 40(8):1966-1986

Rodriguez-Iruretagoiena A, Elejoste N, Gredilla A, Fdez-Ortiz De Vallejuelo S, Arana G, Madariaga JM, De Diego A (2016) Occurrence and geographical distribution of metals and metalloids in sediments of the Nerbioi-Ibaizabal estuary (Bilbao, Basque Country). Mar Chem 185:82-90

Sawulski P, Clipson N, Doyle E (2014) Effects of polycyclic aromatic hydrocarbons on microbial community structure and PAH ring hydroxylating dioxygenase gene abundance in soil. Biodegradation 25:835-847

Schwarzenbach RP, Gschwend PM, Imboden DM (2003) Environmental organic chemistry. Wiley, Totowa

Shallcross LJ, Howard SJ, Fowler T, Davies SC (2015) Tackling the threat of antimicrobial resistance: from policy to sustainable action. Philos Trans R Soc Biol 370:1-5

Singer AC (2017). Pharm J. https://www.pharmaceutical-journal.com/ opinion/comment/how-chemicals-and-heavy-metals-contribute -to-antimicrobial-resistance/20202286. article?firstPass=false

Singer AC, Shaw H, Rhodes V, Hart A (2016) Review of antimicrobial resistance in the environment and its relevance to environmental regulators. Front Microbiol 7:1728

Singleton DR, Jones MD, Richardson SD, Aitken MD (2013) Pyrosequence analyses of bacterial communities during simulated in situ bioremediation of polycyclic aromatic hydrocarbon-contaminated soil. Appl Microbiol Biotechnol 97:8381-8391

Skupinska K, Misiewicz I, Kasprzycka-Guttman T (2004) Polycyclic aromatic hydrocarbons: physicochemical properties, environmental appearance and impact on living organisms. Acta Pol Pharm 61:233-240

Stepanauskas R, Glenn TC, Jagoe CH, Tuckfield RC, Lindell AH, Mcarthur JV (2005) Elevated microbial tolerance to metals and antibiotics in metal-contaminated industrial environments. Environ Sci Technol 39:3671-3678

Stepanauskas R, Glenn TC, Jagoe CH, Tuckfield RC, Lindell AH, King CJ, Mcarthur JV (2006) Coselection for microbial resistance to metals and antibiotics in freshwater microcosms. Environ Microbiol 8:1510-1514

Stogiannidis E, Laane R (2015) Source characterization of polycyclic aromatic hydrocarbons by using their molecular indices: an overview of possibilities. In: Whitacre DM (ed) Reviews of environmental contamination and toxicology. Springer, Cham

Strzebońska M, Jarosz-Krzemińska E, Adamiec E (2017) Assessing historical mining and smelting effects on heavy metal pollution of river systems over span of two decades. Water Air Soil Pollut 228:141

Su JQ, Wei B, Ou-Yang WY, Huang FY, Zhao Y, Xu HJ, Zhu YG (2015) Antibiotic resistome and its association with bacterial communities during sewage sludge composting. Environ Sci Technol 49:7356-7363

Summers AO (2002) Generally overlooked fundamentals of bacterial genetics and ecology. Clin Infect Dis 34(Suppl 3):S85-S92

Sun C, Zhang J, Ma Q, Chen Y (2015) Human health and ecological risk assessment of 16 polycyclic aromatic hydrocarbons in drinking source water from a large mixed-use reservoir. Int J Environ Res Public Health 12:13956-13969

Topp E, Monteiro SC, Beck A, Coelho BB, Boxall ABA, Duenk PW, Kleywegt S, Lapen DR, Payne M, Sabourin L, Li H, Metcalfe CD (2008) Runoff of pharmaceuticals and personal care products following application of biosolids to an agricultural field. Sci Total Environ 396:52-59

Turner PE, Williams ESCP, Okeke C, Cooper VS, Duffy S, Wertz JE (2014) Antibiotic resistance correlates with transmission in plasmid evolution. Evolution 68:3368-3380

Uncles RJ, Stephens JA, Harris C (2014) Freshwater, tidal and wave influences on a small estuary. Estuar Coast Shelf Sci 150 (Part B): $252-261$

Van Dillewijn P, Nojiri H, Der Meer V, Roelof J, Wood TK (2009) Bioremediation, a broad perspective. Microb Biotechnol 2:125-127

Vane CH, Harrison I, Kim AW (2007) Assessment of polyaromatic hydrocarbons (PAHs) and polychlorinated biphenyls (PCBs) in surface sediments of the Inner Clyde Estuary, UK. Mar Pollut Bull 54(8):1301-1306. https://doi.org/10.1016/j.marpo lbul.2007.04.005

Vane CH, Chenery SR, Harrison I, Kim AW, Moss-Hayes V, Jones DG (2011) Chemical signatures of the Anthropocene in the Clyde estuary, UK: sediment-hosted $\mathrm{Pb},{ }^{207 / 206} \mathrm{~Pb}$, total petroleum hydrocarbon, polyaromatic hydrocarbon and polychlorinated biphenyl pollution records. Philos Trans R Soc A: Math, Phys Eng Sci 369(1938):1085-1111. https://doi.org/10.1098/ rsta.2010.0298

Velde B, Barre P (2010) Soils, plants and clay minerals: mineral and biologic interactions. Springer, Berlin

Wang Z, Liu Z, Xu K, Mayer LM, Zhang Z, Kolker AS, Wu W (2014) Concentrations and sources of polycyclic aromatic hydrocarbons in surface coastal sediments of the northern Gulf of Mexico. Geochem Trans 15:2

Wang Z, Su Y, Zhang Y, Guo H, Meng D, Wang Y (2016) Ecologytypes determine physicochemical properties and microbial communities of sediments obtained along the Songhua River. Biochem Syst Ecol 66:312-318

Wang J, Wang J, Zhao Z, Chen J, Lu H, Liu G, Zhou J, Guan X (2017) PAHs accelerate the propagation of antibiotic resistance genes in coastal water microbial community. Environ Pollut 231:1145-1152

Webster L, Fryer RJ, Dalgarno EJ, C M, Moffat CF (2001) The polycyclic aromatic hydrocarbon and geochemical biomarker composition of sediments from voes and coastal areas in the Shetland and Orkney Islands. J Environ Monit 3:491-501

Wellington EMH, Boxall ABA, Cross P, Feil EJ, Gaze WH, Hawkey PM, Johnson-Rollings AS, Jones DL, Lee NM, Otten W, Thomas CM, Williams AP (2013) The role of the natural environment in the emergence of antibiotic resistance in gram-negative bacteria. Lancet Infect Dis 13:155-165

Woodford N, Ellington MJ (2007) The emergence of antibiotic resistance by mutation. Clin Microbiol Infect 13:5-18

World Health Organization (2018) Antimicrobial resistance. http:// www.who.int/mediacentre/factsheets/fs194/en/

Wright MS, Peltier GL, Stepanauskas R, Mcarthur JV (2006) Bacterial tolerances to metals and antibiotics in metal-contaminated and reference streams. FEMS Microbiol Ecol 58:293-302

Yan W, Chi J, Wang Z, Huang W, Zhang G (2009) Spatial and temporal distribution of polycyclic aromatic hydrocarbons (PAHs) 
in sediments from Daya Bay, South China. Environ Pollut 157:1823-1830

Zaaboub N, Martins MVA, Dhib A, Béjaoui B, Galgani F, El Bour M, Aleya L (2015) Accumulation of trace metals in sediments in a Mediterranean Lagoon: usefulness of metal sediment fractionation and elutriate toxicity assessment. Environ Pollut 207:226-237

Zhai Y, He Z, Kang Y, Yu H, Wang J, Du P, Zhang Z, Hu S, Gao Z (2016) Complete nucleotide sequence of pH11, an IncHI2 plasmid conferring multi-antibiotic resistance and multi-heavy metal resistance genes in a clinical Klebsiella pneumoniae isolate. Plasmid 86:26-31

Zhang W, Wang H, Zhang R, Yu XZ, Qian PY, Wong MH (2010) Bacterial communities in PAH contaminated soils at an electronicwaste processing center in China. Ecotoxicology 19:96-104

Zhu Y-G, Johnson TA, Su J-Q, Qiao M, Guo G-X, Stedtfeld RD, Hashsham SA, Tiedje JM (2013) Diverse and abundant antibiotic resistance genes in Chinese swine farms. Proc Natl Acad Sci USA 110:3435-3440 